Ljubodrag Savić $^{1}$
Gorica Bošković $^{2}$
Vladimir Mićićc $^{3}$
JEL: N6, 014, N1, L5

DOI: 10.5937/industrija43-8484

UDC: $330.341 .4: 338.45(497.11)$ 330.342 .4

Original Scientific Paper

\title{
Structural Changes in Manufacturing Industry at Division Level - Serbia and New EU Member States ${ }^{4}$
}

\author{
Article history: \\ Received: 12 June 2015 \\ Sent for revision: 25 June 2015 \\ Received in revised form: 16 September 2015 \\ Accepted: 17 September 2015 \\ Available online: 3 December 2015
}

\begin{abstract}
Research in this paper is oriented towards structural changes at the division level of the manufacturing industry. The goal of the research is to point at the significance of the efficient structural reforms of Serbia's manufacturing industry, more precisely to point at the size, intensity, speed and directions of the changes made in its structure. In the paper, the basic indicators of structural changes are used, namely the trend of the share of employment and the value added. The size of the changes is analyzed by the standard deviation and the dispersion of growth rates, whereas the intensity of changes is analyzed by the elasticity of the divisions' growth rates. A correlation analysis is used to determine the directions and nature of the connectedness of structural changes between divisions, whereas the direction of changes is shown by the Spearman rank correlation coefficient of their growth rates. The Structural Change Indicator is used for researching the pace and patterns of structural changes. At the division level, by applying the comparison method, differences in the directions, speed and patterns of the structural changes of the Serbian manufacturing industry are analyzed against the new EU member states for which there are comparative data (Bulgaria, Romania, Hungary, the Czech Republic, Poland, Slovenia and Slovakia). The research results indicate that growth rates were higher in those divisions in
\end{abstract}

\footnotetext{
${ }^{1}$ University of Belgrade, Faculty of Economics

${ }^{2}$ University of Niš, Faculty of Economics

${ }^{3}$ University of Kragujevac ,Faculty of Economics, micicv@kq.ac.rs.

${ }^{4}$ This paper is the result of the research financed by the Ministry of Science and Technological Development: Project number OI 179028 and III 46001.
} 
Savić LJ. et al.: Structural Changes in Manufacturing Industry at Division Level...

which reforms were more comprehensive, faster, more intensive and efficiently fully implemented.

Key Words: divisions of manufacturing industry, structural changes, employment, added value, industrial policy

\title{
Strukturne promene prerađivačke industrije na nivou oblasti - Srbija i nove članice EU
}

\begin{abstract}
Abstrakt: Istraživanje u ovom radu usmereno je na strukturne promene na nivou oblasti prerađivačke industrije. Cilj istraživanja jeste da ukaže na značaj efikasnih strukturnih reformi prerađivačke industrije Srbije, tačnije da ukaže na veličinu, intenzitet, brzinu i pravace sprovedenih promena njene strukture. $U$ radu su korišćeni osnovni pokazatelji strukturnih promena, odnosno kretanje učešća zaposlenosti $i$ dodate vrednosti. Veličina promena analizira se standardnom devijacijom $i$ disperzijom stopa rasta, a intenzitet promena elastičnošću stopa rasta oblasti. Korelaciona analiza koristi se za utvrđivanje pravaca $i$ prirode povezanosti strukturnih promena između oblasti, dok je pravac promena pokazan Spearmanovim koeficijentom korelacije rangova njihovih stopa rasta. Za istraživanje brzine i obrazaca stukturnih promena korišćen je Indikator strukturnih promena. Na nivou oblasti, primenom metoda komparacije, analiziraju se razlike u pravacima, brzini i obrascima stukturnih promena srpske prerađivačke industrije sa novim članicama EU za koje postoje uporedivi podaci (Bugarska, Rumunija, Mađarska, Češka, Poljska, Slovenija i Slovačka. Rezultati istraživanja pokazuju da su stope rasta bile više $u$ onim oblastima u kojima su reforme bile obuhvatnije, brže, intenzivnije $i$ koje su efikasno dovedene do kraja.
\end{abstract}

Ključne reči: oblasti prerađivačke industrije, strukturne promene, zaposlenost, dodata vrednost, industrijska politika

\section{Introduction}

The size and structure of the manufacturing section of the industry as well as the changes in that structure towards more propulsive, knowledge- and technology-intensive activities, those that create a bigger value added, have an impact on the pace of the growth of the industry and the speed of its development and sustainable economic development. They also influence the production specialization, productivities, the competitiveness, quality and volume of exports (UNIDO, 2013).

The manufacturing industry of Serbia used to have the role of the main driver and bearer of economic development in a longer period. After the year 2000 
Savić LJ. et al.: Structural Changes in Manufacturing Industry at Division Level...

and the intensification of the transition, there have been no serious structural reforms made within the industry, although deep crisis has emerged affecting its development. The effects of the global economic crisis have revealed the weaknesses of the reallocation of employment and production among the activities of the manufacturing industry, which has reflected on the capacity of production and the intensity of industrialization.

Economic practice, and in particular the more recent experiences in the elimination of the consequences of the crisis in 2009, have shown that continuous reforms of the manufacturing industry are very important in developing and transition countries (UNIDO, 2013).

Having in view the foregoing, the subject matter of the research conducted in this paper is structural changes in the production in the manufacturing industry of Serbia, at the division level, which in their turn should be in the function of efficient industrial development. The goal of the research is to point at the significance of the efficient conducting of structural reforms, more precisely to reveal the size, intensity, speed and direction of the changes in the structure of the manufacturing industry made so far.

The paper starts from the following hypotheses: first, stopping the fall and increasing the share of the manufacturing industry of Serbia in production requires bigger, more intensive and more constant structural reforms at the division level; second, the development of the manufacturing industry requires that changes be directed towards the divisions with a higher potential for development, the level of productivity and a bigger value added.

The paper is significant and can be useful to the creators of the industrial policy, which must be active, complete and consistent in order to stimulate and provide directions for continuous structural reforms of the manufacturing industry. Such a policy may have an impact on the creation of a more propulsive manufacturing industry. The condition for continuity is macroeconomic stability, an adequate business ambience, the availability of capital, investments in education, research and development and the development of the infrastructure.

The specificity and originality of the paper reflects in that, differently from the majority of the papers dealing with the analysis of changes in the sectional share and the reallocation of the factors between the economic sections, this paper analyzes the measures of structural change at a lower level as well, i.e. the division level of the manufacturing industry. In order to point at the results of the reforms, the results Serbia has obtained are compared to the results obtained by the selected countries.

The scientific contribution of this paper lies in its critical reappraisal of the results of the structural changes in the manufacturing industry of Serbia as well as pointing at the importance of their more efficient implementation. The 
Savić LJ. et al.: Structural Changes in Manufacturing Industry at Division Level...

paper will in particular indicate the impact that efficient structural changes, and their being directed towards more propulsive divisions have on the creation of a bigger value added at the division level, on which, and to a great extent, the sustainable growth of the manufacturing industry depends. The primary goal of bigger, more intensive and quicker structural reforms towards more propulsive divisions is blocking a further fall in the share of the manufacturing industry in the total employment and production. The basic limitation in the paper is the availability of adequate and comparable data in a longer time period, which excludes the application of other complex indicators by means of which structural changes in the industry are analyzed and measured.

\section{An Overview of the Literature}

Structural changes have an influence on the relative share, significance and location of certain wholes and parts in an economy and they are the drivers of economic development (Syrquin, 2007). They are the source of the growth of the productivity of the production factors (Maddison, 1987). They are liaised with an economy's capability of creating more dynamical activities characterized by greater productivity and bigger yields (Ocampo \& Vos, 2008).

There are numerous researches dealing with the patterns of structural changes and their impact on the economic development of not only developed countries (Timmer, Inklaar, O'Mahony \& Van Ark, 2010; Jorgenson \& Timmer, 2011; Szirmai, Naude \& Alcorta, 2013), but developing countries as well (Bah, 2009; Saccone \& Valli, 2009; Naude, Szirmai \& Lavopa, 2013). Experiences show that industrialization, deindustrialization and reindustrialization have the key effect on the change in the structure of an economy, i.e. change in employment and production between economic activities as well as the characteristics and the process of reforms in the industry. Together with changes in the share of the industry in employment and the GDP, its structure undergoes simultaneous change. Continuous structural changes have an impact on the creation of new and productive production activities, especially in the manufacturing industry, while their more pronounced diversification determines competitiveness, exports and sustainable industrial growth.

While analyzing the relations and directions of structural changes at the level of the manufacturing industry, although they are mainly considered to be universal, the specificities of a country have to be taken into consideration (Cimoli, \& Katz, 2003). At the lower level of economic growth, the main production activities and the main sources of employment and the creation of a newly-created value bear the marks of labor-, resource- and lowtechnology-intensive ones. The growth of the GDP per capita influences 
Savić LJ. et al.: Structural Changes in Manufacturing Industry at Division Level...

structural changes in that they lead to the growth of the share of the production activities, which are technology-mid-intensive. They generate a bigger value added but employ fewer workforce. A high level of the GDP per capita leads to a faster growth and a bigger share of the technology- and knowledge-intensive activities and continuous structural changes and the permanent improvement of the structure of the manufacturing industry.

The direction and intensity of changes, ranging from low-productive to highlyproductive and highly technologically innovative ones, the speed of the creation and expansion of new industries and the reallocation of workers and other factors from traditional to modern and dynamic industries are the essence of changes in the manufacturing industry. Without these changes, there is a small probability that developing countries will achieve long-term economic growth (Rodrik, 2008). Transition to more productive activities should increase the total productivity because, if this is not the case, moving towards activities with a slower growth of productivity can have a negative impact on the growth of the total productivity (Havlik, 2013). Essentially, changing the production structure leads to a transition from lower-value-added products to higher-value-added products. In that way, the growth of production and new jobs are ensured.

The flexible structure of the production of the manufacturing industry is an important element of the growth of productivity. It impacts the efficient reallocation of resources and the use of advantages of technological development and innovations (Fagerberg, 2000). Thus, the level and dynamics of the productivity of labor in the manufacturing industry are influenced in that they strive to be higher than in the other sections and have an impact on the growth of the productivity of labor in those sections (Szirmai, et. al. 2013). The impact on the other sections results from connections, agglomerations, the offer of and demand for products, international trade, investments in research and development, externalities in the development of innovations, the creation of knowledge (Weiss 2011).

When developing countries are concerned, changes in the structure of the manufacturing industry are necessary so as to ensure a higher intensity of the development of the industry and its moving on to a higher development stage. Simultaneously, a failure to implement structural changes and their lagging behind implies the retention of traditional production (Lin, 2012). The removal of structural disproportions and continuous changes in the structure are a very important driver of the transformation of the economies, production specialization, exports and economic development of transition countries. (Havlik, 2005; Russu, 2007; O'Mahony \& Timmer, 2009; Kallioras \& Petrakos, 2010; Timmer, et. al. 2010; Havlik, 2013).

Any inefficient functioning of and a fall in a newly-created value generated by the manufacturing industry of a country certainly require changes in the 
Savić LJ. et al.: Structural Changes in Manufacturing Industry at Division Level...

production structure. If changes are efficient, they increase both productivity and production, while quick and well-implemented changes in the structure modify the results and have an impact on key performances. As the main drivers of structural changes in the manufacturing industry, let us highlight investments, innovations, technologies, know-how, an efficient use of resources and agglomerations (UNIDO, 2013).

The application of the industrial policy is important in the shaping of the structure of developing countries' manufacturing industries (Syrquin, 2007; Lin and Chang, 2009). The role of the industrial policy in those countries also reflects in attracting capital to production so as to increase productivity as well as in joining international production chains and higher-value-added activities (Khan \& Blankenburg, 2009). The industrial policy improves the business environment and encourages structural changes towards the activities with better prospects for growth (Warwick, 2013). The fast-growing economies of the BRIC group of countries stimulate the directing of structural changes (and technological development) by applying an active industrial policy (Naude, et. al. 2013).

\section{The Research Methodology}

In order to test the set hypotheses, the indicators of structural changes, more precisely the share of the manufacturing industry in the total employment and the gross value added (the GVA) it creates in the GDP, are applied. The productivity of the labor of this section is expressed as the difference between the share of the GVA and employment. The size of the structural changes between the divisions of the manufacturing industry is analyzed by means of the standard deviation and the dispersion of the growth rates at the division level. The bigger the dispersion is, the bigger the standard deviation and structural changes are, and vice versa. To be more precise, the standard deviation is a growing function of the structural changes between the divisions of the manufacturing industry.

In order for an analysis of the intensity of structural changes to be carried out, the elasticity of growth rates is used. The intensity of structural changes is determined on the basis of the relative growth rates of each element of the observed structure, and simultaneously the indicator of structural changes is obtained as the arithmetic mean of the sum of the relative growth rates in an absolute expression. The elasticity of growth rates is defined as a ratio between the growth rate of the observed division and the growth rate of the section of the manufacturing industry. A coefficient bigger than one indicates that the divisions are increasing their participation (Roman, 1969). 
Savić LJ. et al.: Structural Changes in Manufacturing Industry at Division Level...

The correlation analysis is applied to determine the directions and nature of the connectedness between structural changes. If structural changes are constantly made in favor of the same elements of a structure, the correlation of the rank is high, and if directions of changes are constantly changed, such a correlation is low. The direction of structural changes is demonstrated by the Spearman Coefficient of the Correlation of the Ranks of the Growth Rates of the Divisions of the Manufacturing Industry for consecutive couples of years (Crkvenac, 1993).

In order to do research into the tempo or the speed and patterns of structural changes, the $\mathrm{S}^{*}$ indicator, i.e. the structural change indicator or the structural deviations indicator, can be used. A lower the $S$ indicator is indicative of slower structural changes and an unchanged structure of a country in a time, and vice versa. It measures the sum of the changes of the share of the divisions of the manufacturing industry in the GVA and employment and it is calculated according to the following formula (Havlik, 2013):

$$
S^{*}=\sqrt{\sum_{k}\left(s h_{k}^{t_{2}}-s h_{k}^{t_{1}}\right)^{2} *\left(s h_{k}^{t_{1}} / 100\right)}
$$

where: $S^{*}$ indicator; $k$ is the observed division of the manufacturing industry, according to the NACE Classification, Revision 2; $s h_{k}$ is the percentage share of the GVA of the division $k$ in the GDP or the percentage share of the division $k$ in the total employment; $t$ stands for the index of time, where $i$ accounts for different years.

By applying the methods of comparison, differences in the structure of the GVA and employment, the productivity, directions, speed and patterns of the structural changes as per divisions of the manufacturing industry of Serbia, Bulgaria, Romania, Hungary, the Czech Republic, Poland, Slovenia and Slovakia will be highlighted. By a comparative analysis, we become aware of the factors that impact the inefficiency of structural changes and the ones that are important for the sustainable growth of the Serbian manufacturing industry. These are the countries in which the data on changes in the structure of the GVA and employment at the level of the divisions of the manufacturing industry are available and comparable for the period from 2000 to 2012.

The section and divisions of the manufacturing industry are defined according to the statistical classification of the activities of the European Union, NACE Revision 2. The level of the aggregation of data is NACE-64, according to which economy encompasses the total of 64 divisions, and the section of the manufacturing industry includes 24 divisions (see Annex, Table 1). In the research, with respect to the observed EU member countries, the data used 
Savić LJ. et al.: Structural Changes in Manufacturing Industry at Division Level...

are possible to find in the statistical database of Eurostat. The statistical database of the Statistical Office of the Republic of Serbia has been the source of the data on the growth rates, employment and the GVA for the divisions of the manufacturing industry of Serbia. Depending on the availability of the data, the same have been observed in the period from 2000 to 2012, and, when available, the same have also been observed for the years 2013 and 2014.

\section{The Research Results}

The level of the share of the manufacturing industry of Serbia in the total employment of over $31 \%$ and of the GVA in the GDP of over $21 \%$ at the beginning of the twentieth century shows that it used to be a rather extremely important economic section (see Annex, Table 2). The intensification of the transition process after 2000 led to an alteration of the significance and relative role of certain sections. In 2012, if compared with the year 2000, the growth of the share of the majority of the service sections, except for the realestate section (Section L), in the GVA and just a slight decrease in the traffic section (Section $H$ ) in the total employment were recorded. Simultaneously, there is an obvious big decrease in the share of the manufacturing section (Section C) in employment and production (Fig. 1).

Deindustrialization is one of the usual features of a transition process. At the same time, a more intensive fall in the share of the industry in the total employment than a fall in the share of the GVA in the GDP is a result of an extensive character of the development of transition countries', and Serbia's as well, industries. Yet, the Serbian economy has been faced with abrupt deindustrialization as the consequence of the inadequate concept of institutional and structural reforms, i.e. the bad privatization and the inadequate restructuring and modernization of enterprises, as well as the inadequate strategy of economic development. The consequences are structural imbalances and the abrupt fall in the share of the industry in employment and the GVA. Disturbances in the world market and the global economic crisis since 2009 have only additionally deepened systemic and structural problems. 
Savić LJ. et al.: Structural Changes in Manufacturing Industry at Division Level...

Figure 1. The sectional change in the share of employment and the GVA in the GDP, 2000-2012, in \%

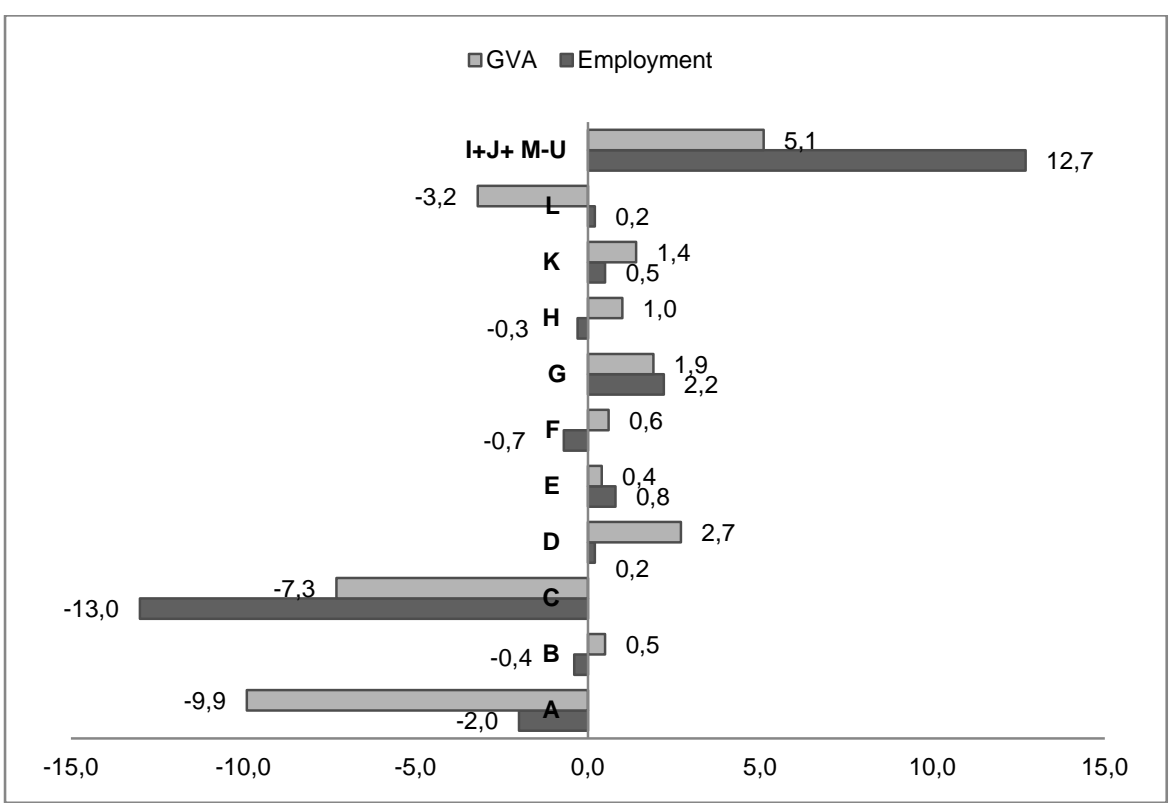

Source: The calculation is made by the Author, on the basis of the data obtained from the databases of the Statistical Office of the Republic of Serbia.

As far as the manufacturing industry of Serbia is concerned, the problems it is being faced with today are the result of the belated, inefficient and bad structural reforms as well as the development in the previous period. Differently from Serbia, the manufacturing industries of the observed countries are being faced with a smaller and milder decline in employment and the GVA. In the Czech Republic, almost $25 \%$ of the totally employed belong to the manufacturing industry. The difference between the share in the GVA and employment in 2013 demonstrates that, together with the Czech Republic, Hungary and Poland, Serbia has a labor-intensive industry, which directly reflects on the level of labor productivity, too. At the same time, the growth of the labor productivity of the manufacturing industry of Serbia is the result of a large and intensive decrease in the number of employees since 2000 (Table 1). 
Savić LJ. et al.: Structural Changes in Manufacturing Industry at Division Level...

Table 1. The share of the manufacturing industry, employment and the GVA in the GDP

\begin{tabular}{|l|c|c|c|c|c|c|c|}
\hline & \multicolumn{3}{|c|}{ Employment } & \multicolumn{3}{c|}{ GVA } & \begin{tabular}{c} 
Difference \\
share of GVA \\
and \\
\cline { 2 - 8 }
\end{tabular} \\
\cline { 2 - 8 } \\
Serbia & 31.4 & 17.1 & -14.3 & 21.7 & 16.1 & -5.6 & $\begin{array}{c}\text { Change } \\
\text { employment in } \\
2013 \text { (3)-2000 }\end{array}$ \\
\hline Bulgaria & 20.1 & 17.6 & -2.5 & 17.6 & 18.2 & 0.6 & -1.0 \\
\hline Romania & 18.6 & 18.1 & -0.5 & 19.8 & 20.2 & 1.0 & 0.6 \\
\hline Hungary & 23.0 & 20.2 & -2.8 & 19.1 & 19.2 & 0.1 & 2.1 \\
\hline $\begin{array}{l}\text { Czech } \\
\text { Republic }\end{array}$ & 27.0 & 24.8 & -2.2 & 23.7 & 22.3 & -1.4 & -1.0 \\
\hline Poland & 20.1 & 18.6 & -1.5 & 16.1 & 16.7 & 0.6 & -2.5 \\
\hline Slovenia & 27.2 & 20.4 & -6.8 & 24.4 & 20.8 & -3.6 & -1.9 \\
\hline Slovakia & 24.5 & 21.6 & -2.9 & 23.8 & 21.7 & -2.1 & 0.4 \\
\hline
\end{tabular}

Source: The calculations are made by the Author, on the basis of the data obtained from the databases of the Statistical Office of the Republic of Serbia and Eurostat.

The analysis carried out at the level of the divisions of the manufacturing industry of Serbia shows that a bigger dispersion of the growth rates of the divisions corresponds to bigger structural changes between the divisions. This is confirmed by the standard deviation of the trends of the growth rates of the divisions per years. The bigger the dispersion is, the bigger the standard deviation is, and vice versa. The divisions whose growth rates record a bigger standard deviation have an increasing share in the structure and are drivers of change (Fig. 2).

In the divisions characterized by a lesser fluctuation in the growth rates, the structural changes are the declining function of the standard deviation. Observed per divisions, the smallest structural changes have been made in the manufacture of food products (C10) and the manufacture of beverages (C11), whereas the biggest changes have been recorded in the divisions of the manufacture of motor vehicles, trailers, and semi-trailers (C 29), the manufacture of other transport equipment (C30), the manufacture of machinery and equipment (C28) and the manufacture of computer, electronic and optical products (C26). 
Savić LJ. et al.: Structural Changes in Manufacturing Industry at Division Level...

Figure 2. The standard deviation of the growth rates of production per the divisions of the manufacturing industry of Serbia, 2000-2014



Source: The calculations are made by the Author, on the basis of the data obtained from the databases of the Statistical Office of the Republic of Serbia.

The analysis of the growth rate confirms the empirical regularities and practical experiences of industrial development implying that dynamic growth rates of different divisions of the manufacturing section precede and influence the creation of the modern and propulsive production structure as well as the relative share, intensity and directions of the development of the structure. For a more dynamic production structure in Serbia to create, the impact of the market alone has not been sufficient; it has rather been necessary that the industrial policy should efficiently be implemented, especially when activating the key factors of structural changes. Unfortunately, this has not happened, so the growth rates could not have been higher, nor could the growth rates of some traditional divisions (the manufacture of food products and beverages) have been higher, either.

The comparative analysis of the standard deviation of the growth rates per the divisions of the manufacturing industry accounts for high values and a dispersion for Serbia, in comparison to the observed countries (for Slovakia and Slovenia, there are no data per divisions available) (Table 2). 
Savić LJ. et al.: Structural Changes in Manufacturing Industry at Division Level...

Table 2. The standard deviation of the growth rates of the divisions of the manufacturing industry throughout 2000-2014

\begin{tabular}{|c|c|c|c|c|c|c|}
\hline Division & Serbia & Bulgaria & Romania & Hungary & Czech R. & Poland \\
\hline C & 6.5 & 9.5 & 5.6 & 8.3 & 6.9 & 5.5 \\
\hline C10 & 4.8 & 7.3 & 7.2 & 4.1 & 5.3 & 2.9 \\
\hline C11 & 7.0 & 12.1 & 12.4 & 5.5 & 7.9 & 6.5 \\
\hline C12 & 9.6 & 11.7 & 16.2 & 27.2 & $/$ & 12.5 \\
\hline C13 & 13.6 & 16.7 & 9.4 & 16.8 & 8.3 & 6.7 \\
\hline C14 & 15.3 & 14.3 & 10.9 & 9.7 & 14.8 & 5.4 \\
\hline C15 & 10.2 & 12.5 & 8.3 & 25.2 & 11.8 & 9.6 \\
\hline C16 & 22.2 & 16.6 & 13.8 & 11.0 & 6.5 & 5.3 \\
\hline C17 & 7.6 & 23.2 & 10.5 & 8.0 & 8.2 & 5.2 \\
\hline C18 & 6.9 & 10.6 & 21.9 & 8.5 & 11.7 & 5.7 \\
\hline C19 & 21.7 & $\ldots$ & 9.3 & 6.4 & 11.7 & 9.4 \\
\hline C20 & 16.8 & 13.9 & 9.2 & 8.1 & 7.6 & 7.6 \\
\hline C21 & 11.7 & 9.9 & 17.8 & 8.1 & 7.7 & 7.9 \\
\hline C22 & 9.9 & 14.4 & 11.7 & 10.2 & 10.0 & 5.9 \\
\hline C23 & 11.1 & 17.2 & 14.6 & 10.9 & 9.1 & 8.1 \\
\hline C24 & 24.1 & 18.1 & 15.1 & 15.9 & 12.3 & 12.6 \\
\hline C25 & 14.1 & 16.1 & 11.9 & 13.4 & 11.7 & 7.5 \\
\hline C26 & 26.9 & 19.7 & 23.0 & 23.1 & 28.3 & 16.2 \\
\hline C27 & 9.3 & 12.7 & 10.9 & 24.8 & 14.6 & 8.2 \\
\hline C28 & 28.1 & 13.3 & 14.0 & 16.1 & 11.9 & 10.0 \\
\hline C29 & 41.0 & 23.5 & 10.5 & 12.6 & 10.5 & 15.3 \\
\hline C30 & 27.1 & 19.5 & 16.0 & 18.8 & 17.2 & 12.8 \\
\hline C31 & 23.2 & 20.6 & 8.6 & 15.0 & 8.1 & 10.2 \\
\hline C32 & 18.5 & 11.9 & 15.0 & 11.6 & 9.1 & 7.0 \\
\hline C33 & 7.6 & 14.5 & 10.4 & 15.6 & 9.3 & 8.7 \\
\hline
\end{tabular}

Source: The calculations are made by the Author, on the basis of the data obtained from the databases of the Statistical Office of the Republic of Serbia and Eurostat.

This can be explained by the fact that the structural changes at the level of the divisions of the manufacturing industry of Serbia are vacillating and belated, i.e. they are more constant in these countries and that these countries were implementing them more intensively prior to 2000 , simultaneously being adequately supported by the industrial policy. A part of these fluctuations can also be explained by adverse market-condition trends, especially in 2008 and 2009 , due to a decline in exports and, at the same time, in the production of the export-oriented divisions.

The analysis of the intensity of the structural changes at the level of the divisions of the manufacturing industry of Serbia shows that the changes are the most intensive in the divisions of the manufacture of motor vehicles, 
Savić LJ. et al.: Structural Changes in Manufacturing Industry at Division Level...

trailers and semi-trailers (C29) and the manufacture of coke and refined petroleum products (C19) (Table 3). This is confirmed by the elasticity of the growth rates of these divisions as well as their average growth rate in the period 2000-2014. The privatization and the volume of investments in those divisions have also influenced the intensity of the structural changes.

Table 3. The divisions of the manufacturing industry of Serbia with the most intensive structural changes, 2000-2014

\begin{tabular}{|l|c|c|}
\hline \multicolumn{1}{|c|}{ Division } & $\begin{array}{c}\text { Elasticity of } \\
\text { growth rates }\end{array}$ & $\begin{array}{c}\text { Average } \\
\text { growth rate }\end{array}$ \\
\hline C 29 Manufacture of motor vehicles, trailers and semi-trailers & 14.6 & 18.7 \\
\hline C 19 Manufacture of coke and refined petroleum products & 6.7 & 8.5 \\
\hline C 21 Manufacture of pharmaceuticals & 4.9 & 6.3 \\
\hline C 24 Manufacture of basic metals & 3.9 & 4.9 \\
\hline C 20 Manufacture of chemicals and chemical products & 3.7 & 4.8 \\
\hline C 27 Manufacture of electrical equipment & 2.8 & 3.5 \\
\hline C 22 Manufacture of rubber and plastic products & 2.4 & 3.1 \\
\hline C 25 Manufacture of fabricated metal products & 2.3 & 3.0 \\
\hline C 17 Manufacture of paper and paper products & 2.0 & 2.6 \\
\hline C 31 Manufacture of furniture & 1.9 & 2.4 \\
\hline C 12 Manufacture of tobacco products & 1.3 & 1.6 \\
\hline
\end{tabular}

Source: The calculations are made by the Author, on the basis of the data obtained from the databases of the Statistical Office of the Republic of Serbia.

The Spearman coefficient of the correlation of the ranks between the growth rates for consecutive couples of years, the 24 divisions of the manufacturing industry of Serbia, shows the direction of the structural changes between these divisions (Table 4). The values of the Spearman coefficient account for the fact that, in the majority of the consecutive years, there is merely slight and relatively weak, and even negative in some years, correlation of the growth rates ranks. It means that the directions of the alteration of the production structure are not consistent and that they do not perform towards the same divisions, but rather to the contrary, the directions of the changes change from one year to another. More importantly, no desired direction of changes has been achieved towards a larger number of propulsive divisions creating a bigger value added.

The results of the assessments of the speed as well as the patterns of the structural changes are accounted for in Tables 5 and 6 . They consist of the sum of the changes of the share of the 24 divisions in the structure of the GVA and employment of the manufacturing industry of Serbia and the observed countries for the period 2000-2012, as well as for different periods prior to and after the breaking of the global economic crisis, which comparable data are available for. 
Savić LJ. et al.: Structural Changes in Manufacturing Industry at Division Level...

Table 4. The Spearman Ranks Correlation Coefficient

\begin{tabular}{|c|c|c|c|}
\hline & $\begin{array}{c}\text { Correlation } \\
\text { Coefficient }\end{array}$ & $\begin{array}{c}\text { Sig. } \\
\text { (2-tailed) }\end{array}$ & $\mathrm{N}$ \\
\hline $2000 / 01$ & 0.080 & 0.709 & 24 \\
\hline $2001 / 02$ & -0.151 & 0.482 & 24 \\
\hline $2002 / 03$ & 0.255 & 0.230 & 24 \\
\hline $2003 / 04$ & 0.338 & 0.106 & 24 \\
\hline $2004 / 05$ & 0.300 & 0.154 & 24 \\
\hline $2005 / 06$ & $0.531^{\star *}$ & 0.008 & 24 \\
\hline $2006 / 07$ & -0.123 & 0.567 & 24 \\
\hline $2007 / 08$ & 0.153 & 0.475 & 24 \\
\hline $2008 / 09$ & 0.171 & 0.424 & 24 \\
\hline $2009 / 10$ & 0.000 & 1.000 & 24 \\
\hline $2010 / 11$ & -0.157 & 0.463 & 24 \\
\hline $2011 / 12$ & $0.535^{\star *}$ & 0.007 & 24 \\
\hline $2012 / 13$ & 0.233 & 0.272 & 24 \\
\hline $2013 / 14$ & $-0.478^{*}$ & 0.018 & 2 \\
\hline
\end{tabular}

* Correlation is significant at the 0.05 level (2-tailed); ${ }^{*}$ Correlation is significant at the 0.01 level (2-tailed). Source: The Author's calculations.

The speed of the structural changes of the GVA per the divisions of the manufacturing industry differs between Serbia and the observed countries as well as per periods (Table 5). From 2000 to 2012, the fastest and the most stable changes were recorded by Slovakia, the Czech Republic, Hungary and Slovenia, whereas they were the slowest in Poland. Such a trend has remained even once the observed countries became the EU member countries. Since 2009, except for Slovakia, all the other countries have significantly been experiencing a slowdown in structural changes, particularly Serbia and Poland. In the period preceding 2008, Slovakia and Serbia were in the forefront when the speed of reform making is concerned. The high speed of structural changes in Serbia in the period 2000-2008 can be explained by the privatization which the observed countries had for the most part gone through prior to the year 2000.

Table 5. The indicator of the structural changes S-GVA

\begin{tabular}{|l|c|c|c|c|}
\hline & $\mathbf{2 0 1 2 - 2 0 0 0}$ & $\mathbf{2 0 1 2 - 2 0 0 5}$ & $\mathbf{2 0 1 2 - 2 0 0 9}$ & $\mathbf{2 0 0 8 - 2 0 0 0}$ \\
\hline Serbia & 0.315 & 0.320 & 0.071 & 0.351 \\
\hline Bulgaria & 0.291 & 0.197 & 0.114 & 0.280 \\
\hline Romania & 0.320 & 0.328 & 0.211 & 0.277 \\
\hline Hungary & 0.381 & 0.387 & 0.176 & 0.257 \\
\hline Czech Republic & 0.445 & 0.249 & 0.201 & 0.314 \\
\hline Poland & 0.116 & 0.057 & 0.060 & 0.115 \\
\hline Slovenia & 0.356 & 0.138 & 0.102 & 0.334 \\
\hline Slovakia & 0.540 & 0.481 & 0.342 & 0.398 \\
\hline
\end{tabular}

Source: The calculations are made by the Author, on the basis of the data obtained from the databases of the Statistical Office of the Republic of Serbia and Eurostat. 
Savić LJ. et al.: Structural Changes in Manufacturing Industry at Division Level...

The speed of the structural changes in employment in the divisions of the manufacturing industry differs in certain countries and periods as well as they do in relation to the speed and patterns of the structural changes in the GVA (Table 6). The speed of the changes varies per the observed periods and there is no clear pattern. In the period 2000-2012, Slovenia is the one to have recorded the fastest and the most stable restructuring, whereas Bulgaria and Romania are the ones to have recorded the slowest such restructuring. From 2005 to 2012, Serbia, Romania and Bulgaria recorded an increase in the speed of changes in employment, whereas a slowdown was recorded in the other countries. In the period 2009-2012, Romania is the only one country to have achieved a smaller decrease in the speed of the structural changes in employment between the divisions, whereas all the other countries recorded a major slowdown in the speed of the reforms.

Table 6. The indicator of the structural changes S-employment

\begin{tabular}{|l|c|c|c|c|}
\hline & $\mathbf{2 0 1 2 - 2 0 0 0}$ & $\mathbf{2 0 1 2 - 2 0 0 5}$ & $\mathbf{2 0 1 2 - 2 0 0 9}$ & $\mathbf{2 0 0 8 - 2 0 0 0}$ \\
\hline Serbia & 0.291 & 0.305 & 0.075 & 0.153 \\
\hline Bulgaria & 0.201 & 0.300 & 0.069 & 0.447 \\
\hline Romania & 0.201 & 0.391 & 0.335 & 0.263 \\
\hline Hungary & 0.519 & 0.186 & 0.109 & 0.479 \\
\hline Czech Republic & 0.345 & 0.321 & 0.074 & 0.318 \\
\hline Slovenia & 0.742 & 0.307 & 0.088 & 0.546 \\
\hline Slovakia & 0.518 & 0.346 & 0.116 & 0.425 \\
\hline Poland & 0.293 & 0.214 & 0.054 & 0.172 \\
\hline
\end{tabular}

Source: The calculations are made by the Author, on the basis of the data obtained from the databases of the Statistical Office of the Republic of Serbia and Eurostat.

The speed and patterns of the structural changes in the GVA and employment of the manufacturing industry of Serbia prior to and after the crisis have been caused by the non-existence of an adequate strategy of its development and an appropriate industrial policy. The global economic crisis has had as a consequence the slowdown and stagnation of the institutional, economic and structural reforms. The problems of the restructuring of non-privatized enterprises and those in bankruptcy, as well as the re-privatization of the enterprises whose privatization has been declared null and void, are slowly solved. Insufficient investments in the majority of the production divisions as well as a smaller-than-expected inflow of foreign capital since 2010, which are important drivers of the structural reforms of the manufacturing section, only attach to this.

The consequences different in the size, intensity, speed and directions of the changes in the production structure are illustrated by the distribution of the 
Savić LJ. et al.: Structural Changes in Manufacturing Industry at Division Level...

GVA according to the leading production divisions of Serbia and the observed countries (Fig. 3).

Figure 3. The leading divisions of production - the share of the GVA in the GDP, in 2012

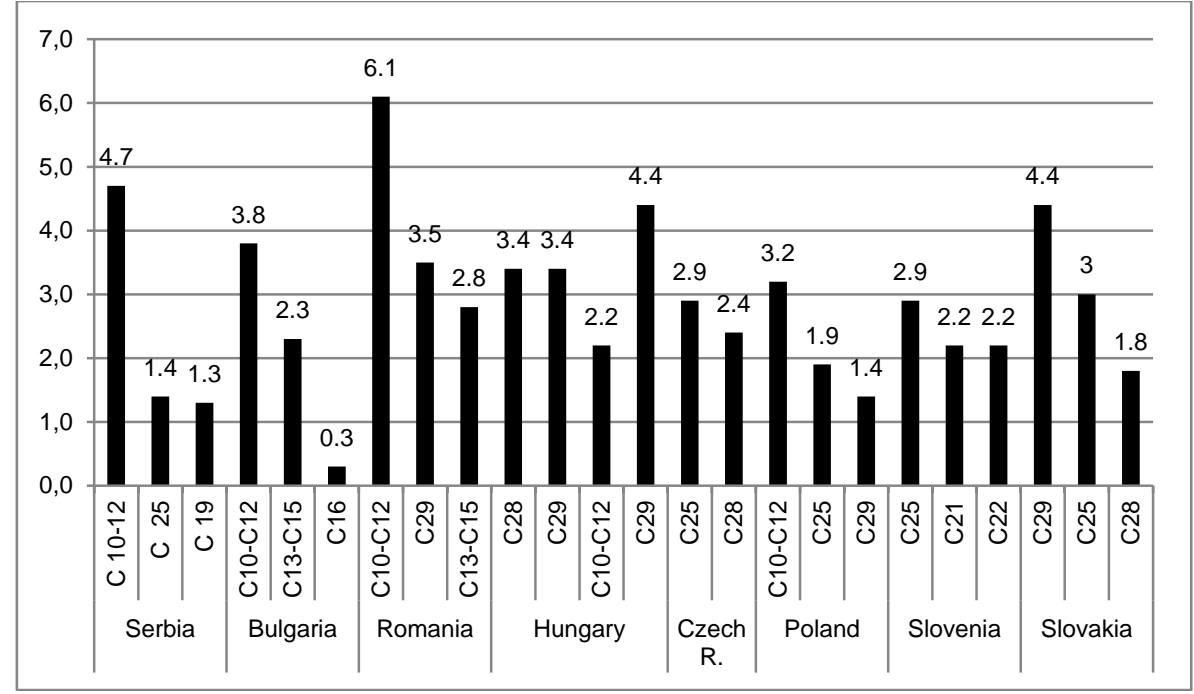

Source: The calculations are made by the Author, on the basis of the data obtained from the databases of the Statistical Office of the Republic of Serbia and Eurostat.

The data available show that the manufacture of food products and beverages, the manufacture of basic and prefabricated metals products, and the manufacture of coke and refined petroleum products prevail in Serbia. These are resources and labor-intensive products as well as low- and middlelow-technology-intensive products (see Annex, Table 3). Both Bulgaria and Romania also have a high-ranking share in the manufacturing of food products and beverages as well as a high share of the textile industry. In Poland, the manufacture of food products and beverages, basic and prefabricated metal products as well as motor vehicles, trailers and semitrailers and other transport equipment has a big share. In the manufacturing done in Slovakia, the Czech Republic, Hungary and Slovenia, the divisions of the manufacture of motor vehicles, trailers and semi-trailers and other transport equipment, machinery and equipment, chemicals and chemical products and basic and prefabricated metal products are prevalent.

These are middle-high- and middle-low-technology-intensive and labor-knowhow-intensive products. These divisions are at a higher level of productivity and create a bigger value added. 
Savić LJ. et al.: Structural Changes in Manufacturing Industry at Division Level...

Apart from production specialization, the leading divisions are also indicative of the key bearers of the development of the industries of the observed countries. Their structure and share in the GVA show that their developmental impact and potential are bigger in the observed countries than they are in Serbia. This is thanks to directing the structural changes towards the growth of the production of products which are middle-high-technology-intensive and to decreasing labor- and resource-intensive production. When changing their production orientations, these countries also took into consideration the markets deemed to be the biggest markets for importing industrial products in the EU market, and in particular the divisions considered to be the most propulsive ones in the EU industry.

\section{Conclusion}

The structural changes in the Serbian economy have had an influence on the decline in the share of the manufacturing industry in the total employment and production, which has led to a change in the relative role and a decrease in its significance in the post-2000 economic development. Simultaneously, the changes in employment are more pronounced than the ones in production, which impacts the labor productivity trends. The decrease in its significance occurred due to the inefficient structural reforms, the numerous systemic problems, the inefficient institutional changes, the bad concept of privatization as well as the disturbances in the world market in 2009.

Sufficiently comprehensive, quick and intensive changes have not been implemented in the manufacturing industry of Serbia, i.e. there are a small number of divisions characterized by more dynamic growth rates and highly intensive changes. Changes are also belated, insufficiently constant and are not being made towards the same divisions to be able to have an influence on the changing of the production structure. This practically confirms the hypothesis that blocking the fall and increasing the share of the manufacturing industry in manufacturing requires bigger, more intensive and more constant structural reforms at the division level. A future development of the manufacturing industry will directly depend on the speed and intensity of changes and the creation of a modern and propulsive production structure.

The size, intensity, speed and directions of the structural changes between the divisions of the manufacturing industry of Serbia have an influence on the structure and distribution of the GVA. The traditional production of resourceand labor-intensive products and those bearing a low and middle-low technological content, whose potentials, on the other hand, have not been utilized to a sufficient extent, as is the case in the divisions of the manufacture of food products and beverages, is predominant. This confirms the second hypothesis that in order for the manufacturing section to develop, it is 
Savić LJ. et al.: Structural Changes in Manufacturing Industry at Division Level...

necessary that changes be directed towards the divisions that are characterized by a bigger potential for development, are at a higher productivity level and have a bigger value added.

The changes in the volume and the structure of the GVA of the Serbian manufacturing industry show that it consists of the divisions creating a small value added. For that reason, it is important that, in further researches, we should see to what extent change, first of all an increase in the GVA in some divisions, is connected with an inflow of foreign capital and a technology transfer, by taking comparative advantages and by exporting.

In order to establish a more propulsive production structure in the forthcoming period, it is necessary that industrial policy should be active and put a special stress on the reallocation of the production factors into more productive divisions of the manufacturing industry, the divisions generating bigger yields and those export-oriented. Its important role is also reflected in activating the key factors of structural changes such as investments, the transfer and application of technological innovations and knowledge, and providing directions for the basic directions and pillars of development.

\section{References}

Bah, E.H. (2009). Structural Transformation in Developed and Developing Countries.

Cimoli, M., \& Katz, J. (2003). Structural reforms, technological gaps and economic development: A Latin American perspective. Industrial and Corporate Change, 12(2), 387-411. 12(2): 387-411. doi:10.1093/icc/12.2.387

Crkvenac, M. (1993). Ekonomika industrije i gospodarski razvoj Hrvatske. , 260-261.

Fagerberg, J. (2000). Technological Progress, Structural Change and Productivity Growth: A Comparative Study. Structural Change and Economic Dynamics, 11(4), 393-418.

Jorgenson, D.W., \& Timmer, M.P. (2011). Structural Change in Advanced Nations: A New Set of Stylised Facts.Scandinavian Journal of Economics, 113(1), 1-29.

Kallioras, D., \& Petrakos, G. (2010). Industrial growth, economic integration and structural change: Evidence from the EU new member-states regions. Annals of Regional Science, 45(3), 667-680.

Khan, M., \& Blankenburg, S. (2009). The Political Economy of Industrial Policy in Asia and Latin America. In G. Dosi, M. Cimoli, \& J.E. Stiglitz (Eds.), Industrial Policy and Development: The Political Economy of Capabilities Accumulation. Oxford: Oxford University Press.

Havlik, P. (2005). Central and East European industry in an enlarged European Union: Restructuring, specialisation and catching-up. Économie internationale, 2, 107132.

Havlik, P. (2013). Structural Change and Economic Growth in the New EU Member States, Growth-Innovation-Competitiveness: Fostering Cohesion in Central and Eastern Europe. The Vienna Institute for International Economic Studies. 
Savić LJ. et al.: Structural Changes in Manufacturing Industry at Division Level...

Lin, Y.J. (2012). New Structural Economics: A Framework for Rethinking Development and Policy. Washington: World Bank.

Lin, J.Y., \& Chang, H.J. (2009). Should Industrial Policy in Developing Countries Conform to Comparative Advantage or Defy it. Development Policy Review, 27(5), 483-502.

Maddison, A. (1987). Growth and slowdown in advanced capitalist economies: Techniques of quantitative assessment.Journal of Economic literature, 649-698.

Naude, W., Szirmai, A., \& Lavopa, A. (2013). Industrialization lessons from BRICS: A comparative analysis. (pp. 1-3).

Syrquin, M. (2007). Structural Change and Development. In A. Dutta \& C. Ros (Eds.), International Handbook of Development Economics. UK: Edward Elgar Publishing.

Szirmai, A., Naude, W., \& Alcorta, L. (2013). Introduction and Overview: The Past, Present and Future of Industrialization. In A. Szirmai, W. Naude, \& L. Alcorta (Eds.), Pathways to Industrialization in the Twenty-First Century-New Challenges and Emerging Paradigms. Oxford: Oxford University Press.

Ocampo, J.A., Vos, R., \& Eds., (2008). Uneven economic development. United Nations Publications.

O'mahony, M., \& Timmer, M.P. (2009). Output, input and productivity measures at the industry level: The eu klems database. Economic Journal, 119(538),

Rodrik, D. (2008). Normalizing industrial policy. In Commission on growth and development working paper. Washington: World Bank. Retrieved from http://documents.worldbank.org/curated/en/2008/01/13163290/normalizingindustrial-policy

Roman, Z. (1969). A note on measuring structural changes. Review of Income and Wealth, 15(3), 265-268. 15(3): 265-268. doi:10.1111/j.14754991.1969.tb00809.x

Russu, C. (2007). Structural Changes of the Manufacturing Industry of the European Union Member Countries and their Specialization. Change, 1995.

Saccone, D., \& Valli, V. (2009). Structural change and economic development in China and India. In University of Torino Department of Economics Research Paper.

Timmer, M.P., Inklaar, R., O'mahony, M., \& Van, A.B. (2010). Economic growth in Europe: A comparative industry perspective. Cambridge University Press.

-UNIDO. (2013). Industrial Development Report 2013, Sustaining Employment Growth: The Role of Manufacturing and Structural Change. Vienna.

Warwick, K. (2013). Beyond Industrial Policy: Emerging Issues and New Trends. OECD Science, Technology and Industry Policy Papers, 2, doi:10.1787/5k4869clw0xp-en

Weiss, J. (2011). Industrial Policy in the Twenty-First Century: Challenges for the Future. Helsinki: UNU World Institute for Development Economics Research. Working Paper. 
Savić LJ. et al.: Structural Changes in Manufacturing Industry at Division Level...

\section{Annex}

Table 1. Industry $(B, C, D)$, codes per sections and divisions - NACE Revision 2 , level 64 of activities

\begin{tabular}{|l|}
\hline B - Mining and quarrying \\
\hline B 05 Mining of coal and lignite \\
\hline B 06 Extraction of crude petroleum and natural gas \\
\hline B 07 Mining of metal ores \\
\hline B 08 Other mining and quarrying \\
\hline B 09 Mining support services \\
\hline C - Manufacturing \\
\hline C 10 Manufacture of food products \\
\hline C 11 Manufacture of beverages \\
\hline C 12 Manufacture of tobacco products \\
\hline C 13 Manufacture of textiles \\
\hline C 14 Manufacture of wearing apparel \\
\hline C 15 Manufacture of leather and related products \\
\hline C 16 Manufacture of wood and wood products \\
\hline C 17 Manufacture of paper and paper products \\
\hline C 18 Printing and reproduction of recorded media \\
\hline C 19 Manufacture of coke and refined petroleum products \\
\hline C 20 Manufacture of chemicals and chemical products \\
\hline C 21 Manufacture of pharmaceuticals \\
\hline C 22 Manufacture of rubber and plastic products \\
\hline C 23 Manufacture of other non-metallic mineral products \\
\hline C 24 Manufacture of basic metals \\
\hline C 25 Manufacture of fabricated metal products \\
\hline C 26 Manufacture of computer, electronic and optical products \\
\hline C 27 Manufacture of electrical equipment \\
\hline C 28 Manufacture of machinery and equipment \\
\hline C 29 Manufacture of motor vehicles, trailers and semi-trailers \\
\hline C 30 Manufacture of other transport equipment \\
\hline C 31 Manufacture of furniture \\
\hline C 32 Other manufacturing \\
\hline C 33 Repair and installation of machinery and equipment \\
\hline D - Electricity, gas, steam and air conditioning supply \\
\hline D 35 Electricity, gas, steam and air conditioning supply \\
\hline
\end{tabular}


Savić LJ. et al.: Structural Changes in Manufacturing Industry at Division Level...

Table 2. The National Account, code of section - NACE Revision 2, level 21 of activities

\begin{tabular}{|l|}
\hline A Agriculture, forestry and fishing \\
\hline B Mining and quarrying \\
\hline C Manufacturing \\
\hline D Electricity, gas, steam and air conditioning supply \\
\hline E Water supply; sewerage, waste management and remediation \\
activities \\
\hline F Construction \\
\hline G Wholesale and retail trade \\
\hline H Transportation and storage \\
\hline I Accommodation and food service activities \\
\hline J Information and communication \\
\hline K Financial and insurance activities \\
\hline L Real estate activities \\
\hline M Professional, scientific and technical activities \\
\hline N Administrative and support service activities \\
\hline O Public administration and defence; compulsory social security \\
\hline P Education \\
\hline Q Human health and social work activities \\
\hline R Arts, entertainment and recreation \\
\hline S Other service activities \\
\hline T Activities of households as employers \\
\hline U Activities of extraterritorial organisations and bodies \\
\hline
\end{tabular}

Table 3. Classification of the divisions of the manufacturing industry according to the technological intensity of production, OECD

\begin{tabular}{|l|l|}
\hline High-technology & C 21 and C 26 \\
\hline Medium-high-technology & C 20 and C 27-30 \\
\hline Medium-low-technology & C 19, C 22-25 and C 33 \\
\hline Low-technology & C 10 -18 and C 31-32 \\
\hline
\end{tabular}

